\title{
TRANSLATION AND DICTIONARIES IN FOREIGN LANGUAGE ACQUISITION: THE CASE OF THE LATVIAN LANGUAGE
}

\author{
Diāna Laiveniece, ${ }^{1}$ Linda Lauze ${ }^{2}$
}

\begin{abstract}
In modern linguodidactics, there is no uniform understanding of the necessity of translation in the acquisition of a foreign language. The aim of the research is to find out the language attitudes held by full-time and Erasmus exchange program foreign students towards translation in acquiring Latvian as a foreign language on language proficiency level A1 and A2.

The research is based on a qualitative study dealing with the results of survey data as well as direct observations inferred from the work with foreign students. The questionnaire consists of 11 questions on translation and usage of dictionaries and a question about personal information. The answers of 35 respondents from 12 countries have been analyzed. $91.43 \%$ of the respondents enjoy translation tasks, only $8.57 \%$ of answers are negative. The highest evaluation was given for word translation, that is, 4.23 for translation from a foreign language (Latvian) into English (being the intermediary language) and 4.15 the other way round in a five point scale. Diverse linguistic experience, differences among language systems, students' language attitudes establish the purposeful use of translation in foreign language acquisition.
\end{abstract}

UDC Classification: 8111; DOI: http://dx.doi.org/10.12955/cbup.v5.1008

Keywords: Latvian as foreign language, foreign language acquisition, translation, dictionary, plurilingual teaching/learning environment

\section{Introduction}

Translation is a major component in foreign language acquisition at an early stage, particularly at A1 and A2 level, when learners' knowledge of English is insufficient, minimal or the learners even do not know the language at all. Translation is one of the ways that serve as a transition from one language to the other. It is either used automatically or in cases when the teacher asks students to translate. In most cases, we translate a foreign word, sentence or text if we do not understand them. Language learning is, in any event, a transference process in which literal, word-for-word translation is essential at early stages.

In some publications authors (Carreres, 2006; Marqués-Aguado, Solís-Becerra, 2013; Mutore, 2013) compare didactic guidelines on translation as a tool for language acquisition in the education process of translators and interpreters. Also, the Common European Framework of Reference (CEFR) for Languages focuses on mediation strategies when discussing language learner's communication. "In mediating activities, the language user is not concerned to express his/her meanings, but simply to act as an intermediary between interlocutors who are unable to understand each other directly [..]. Examples of mediating activities include spoken interpretation and written translation as well as summarising and paraphrasing texts in the same language when the language of the original text is not understandable to the intended recipient." (CEFR, 2001, p. 87) To translate orally or in a written form, one's command of the language is to be on a rather high level. This study focuses on the early stage of foreign language learning when translation helps to understand the person who learns the language rather than others, so this aspect will not be discussed in more detail.

\section{Methodology}

The aim of the research is to find out language attitudes held by full-time and Erasmus exchange program foreign students towards translation in acquiring Latvian as a foreign language on language proficiency level A1. Studies on updating translation in the acquisition of foreign languages form the theoretical basis of the research (Cook, 2010; Leonardi, 2011; Mogahed, 2011; Dagiliene, 2012; Tsagari, Floros, 2013; Fernández-Guerra, 2014, etc.). The empirical part of the research is based on a qualitative study dealing with the results of survey data carried out in 2017 as well as direct observations inferred from the work with foreign students. The questionnaire consists of 11 questions on translation and usage of dictionaries and a question about personal information (age, gender, native language, and proficiency in foreign languages). The sample consisted of 35 respondents -11 female

\footnotetext{
${ }^{1}$ Faculty of Humanities and Arts, Liepāja University, diana.laiveniece@liepu.lv

${ }^{2}$ Faculty of Humanities and Arts, Liepāja University, linda.lauze@liepu.lv
} 
and 24 male, 19-45 year old bachelor and master level students from 12 countries (Lithuania, Portugal, Ukraine, Turkey, India, Sri Lanka, Pakistan, China, Russia, USA, Germany, Nepal). Students mentioned 13 different mother tongues (Urdu, Tamil, Punjabi, Turkish, Hindi, Sinhala, Nepali, Lithuanian, Russian, Chinese, German, Portuguese, Ukrainian), three respondents were bilingual (English/ Russian; Tamil/Sinhala; Urdu/Panjabi). All respondents understand English, to about a half of them English is the only foreign language, but 17 students indicated that they know other foreign languages at different levels, in some cases, also mentioning Latvian language skills. The research also analyses the usage of dictionaries in learning the Latvian language as a foreign language.

\section{Results}

First, it was found out in the survey what respondents do if they do not know the meaning of a word, by offering the possibility to mark several options of the six answers provided (see Figure 1). In general, foreign students have ticked 64 choices, preferring the answer look it up in a bi-lingual dictionary $(29.69 \%)$. Direct observations show that in cases in which students have chosen the option toask somebody for help (15.62\%) it reflects two kinds of activities - during a class ask a course mate who is also a foreign student or the language teacher and outside classes ask a native speaker that is usually a student living in the university dormitory. It should be noted that the respondents' knowledge of the language is not sufficient yet to analyze the usage of the new word in context as they are elementary learners. This option is selected just by $10.94 \%$ of the respondents who know some other foreign language, quite often even two, three or four languages. Students use bi-lingual dictionaries more often than explanatory dictionaries. It corresponds to learners' language skills necessary for simple language proficiency level, that is, students can use a bilingual dictionary and are aware of the need to check the used words and their meanings carefully (Šalme, Auzina, 2016, p. 174).

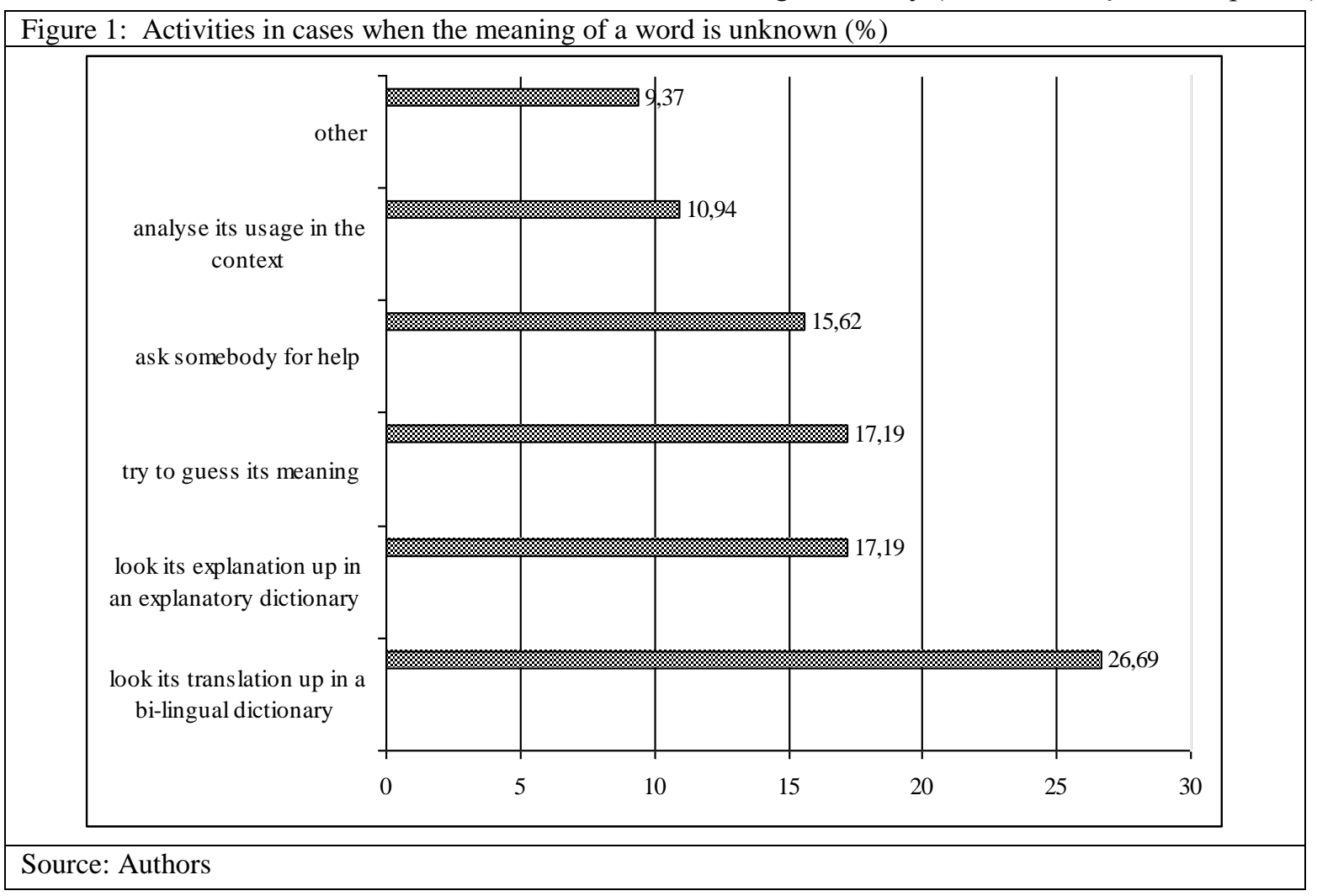

Analysing the current issue Do you consider a book format dictionary or a digital one to be more convenient for usage in language acquisition? Why? We can conclude that $81.82 \%$ of the respondents consider digital dictionaries as the most suitable ones, $9.09 \%$ of the students use both types of 
dictionaries, but $9.09 \%$ point out the advantages of paper format dictionaries. There are some common positions ${ }^{3}$ :

- I use both versions. However, during the last three years I used the Google version as it is faster than the standard dictionary (male, 45, USA);

- Digital one. Easy to search, easy to use, handy (male, 28, Pakistan);

- I prefer digital one because on the Internet I can listen to the pronunciation and learn the language better (male, 21, Pakistan);

- Digital ones are easier to use, but I like a book format dictionary and touching a real dictionary. Reading explanations from them is more permanent (female, 19, Turkey);

- I consider a book format because it is easy to understand (male, 25, India).

Students highlight the following advantages of digital dictionaries: they are modern, you can quickly find and understand words, they are portable, and you can hear the pronunciation of the word. The authors can agree with a foreign student who says:

- The digital dictionary is very useful because it's easy to take away like in the phone and it is updating after some time. So, that's why we are able to set more information (male, 32, Pakistan).

Another advantage is that the words are arranged in a definite system and that it is easy to understand the meaning of a word.

Since learning a foreign language is connected with specific cultural and social differences, pictures can help with getting to know the meaning of new words. For example, learning the vocabulary concerning fruit, a picture of a melon may assist the student to understand that the Latvian language has two different words: melone ('melon')and arbüzs ('water-melon'). When teaching the phrase bèrzu sula ('birch sap') pictures of a birch and birch sap help students to have an idea of this drink. All respondents $(100 \%)$ confirmed that pictures are useful for understanding the meaning of a new word when it is necessary to clarify it.

In the survey respondents were asked to rate the usefulness of the translation, both from Latvian into English and from English into Latvian, as a means of learning a foreign language. Translation of different level language units (a word, a phrase, a grammatical unit, and a text) was assessed on a fivepoint scale where one stands for not at all useful and 5 for very helpful. In all the translation positions the index is higher than 3.5 (see Figure 2). In the translation from the Latvian language into English, word translation ranks highest -4.23 , and translation of a grammatical unit is the lowest -3.51 points. There are slight differences in the translation assessment from the English language into Latvian. The translation of a word ranks the highest here as well -4.15 points and the translation of a grammatical unit is the lowest as well -3.67 points. The results show that elementary learners are not yet aware of the significance of the word's grammatical meaning. In flective languages, both lexical and grammatical meanings of the word are important to understand a text.

\section{Discussion}

In modern linguodidactics, there is no uniform understanding of the necessity of translation in the acquisition of a foreign language. The question about translation as a teaching method and the use of it in foreign language acquisition has become essential in the recent ten years. Currently, there are radically restrictive policies. In some researches translation is disproved and considered as an artificial, unproductive, totally useless exercise and a frustrating, not motivating learning activity (see for example Fernández-Guerra, 2014, p. 154). Other researchers, on the contrary, point out that translation is a cognitively meaningful and purposeful language learning exercise.

In some foreign language learning methods, such as in the grammar translation method, translation is one of the most important training techniques. It helps learners to more accurately understand whether the meaning of words, their grammar forms, and syntactical structures are similar in their native language or the intermediary language to those in the target language they learn (Skujinna, 2011, p. 91).

\footnotetext{
${ }^{3}$ In their answers students' use of language is preserved.
} 


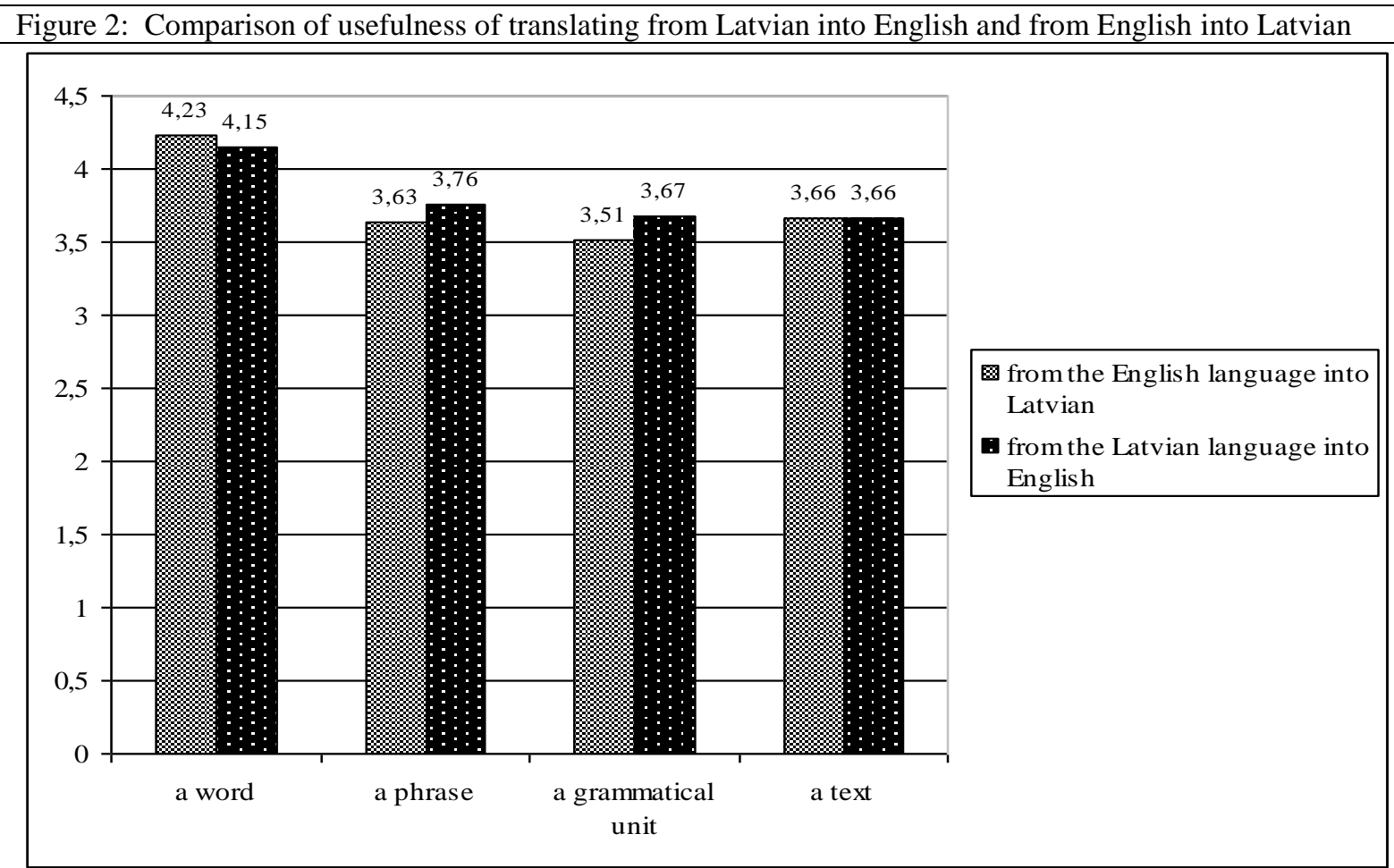

Source: Authors

Whether the translation component from the classical methods of foreign language acquisition will be integrated into the modern teaching methods - that is the question that is currently topical for foreign language teachers. There is an opinion that translation as one of the foreign languages learning techniques is suitable for teaching literary (formal) language or working with linguistically oriented language learners who like learning grammar and vocabulary in detail (Carreres, 2006). Whereas, when teaching the so-called "average learners," translation is completely inappropriate. It is well known that translation is a complex activity associated with language, culture, communication and cognitive factors (Fernández-Guerra, 2014, p. 157). Therefore, not all language learners can do a qualitative translation.

At the beginning of the $21^{\text {st }}$ century the issue of using translation in the foreign language learning process and the productivity of the communicative approach, as well as the evaluation of modern teaching methods,has become topical (see for exampleCook, 2010; Tsagari, Floros, 2013). In the previous centuries, when foreign language learning was dominated by other approaches, mainly the above mentioned grammar translation method, translation as a right or wrong teaching method was not discussed or considered. Nowadays there is a need to improve the communicative language learning method by adding translation tasks (Mutore, 2013, p. 96). It is undoubtedly influenced by the availability of new technologies - if learners have a Smartphone, they also have the most extensive translation options.

It is more and more increasingly stressed that translation itself is a useful skill. In the globalized world and multilingual society, translation as a means of public communication is around us. We see it in announcements, labels, menus, news subtitles, etc. (English Language Teaching Global Blog 2011) and it is just logical to consider the question how to use translation in language learning.

To understand the issue of "for and against translation in language learning," it is worth learning more about at least one publication against translation in language learning and try to rebut it taking into account recent positions. For example, in the introduction of the book "Translation and Language Teaching" seven arguments are mentioned against the use of translation in language acquisition (Malmkjær 1998, p. 6). The interpretation of these arguments follows, and they are at least partly rebutted from a modern foreign language learner. 
1. Translation is independent and radically different from the four skills which define language competence: reading, writing, speaking, and listening. Rebuttal: for some time already thinking is considered to be the fifth language skill (Fisher, 1990). You cannot use the language without thinking. Translation, if it exceeds the boundaries of one lexeme, requires lots of thinking, so, when you translate, your habit to think about language is developed which in its turn contributes to the development of all four language skills above mentioned.

2. Translation takes up valuable time which could be used to teach those four skills. Rebuttal: you do not need to do translation during all language lesson, though translation can be helpful to develop the skills of independent work.

3. Translation is unnatural. Rebuttal: in today's dynamic world it is not possible for monolingual speakers to learn all the necessary foreign languages at a level of the native language or for bilingual language users at a level of the first and the second language, so the translation is a natural daily necessity (see more: Leonardi 2011).

4. Translation misleads and prevents students from thinking in the foreign language. This view can be partially accepted, but only in respect of productive language skills: speaking and writing. Reproductive language skills (listening and reading) are improved by using translation.

5. Translation is a severe test of language skills. Rebuttal: translation cannot be the only way of testing language skills, but it is beneficial for testing vocabulary.

6. Translation produces interference. Rebuttal: interference is a natural consequence phenomenon of two language contacts, which is reinforced not by literally translating words and phrases but by the uncritical attitude to the use of language.

7. Translation is only appropriate for training translators. Rebuttal: if the translation were applied only to the education of interpreters and translators, the mutual impact and interconnection of both areas - didactics of translation and language learning would not be widely studied.

In the process learning the Latvian language as a foreign language, translation is not used to translate everything that learners do not know, but only in some cases when there is a reason to believe that learners have not understood something. In such situations, it is essential not to translate the entire sentence or text, but to highlight only some words or phrases and ask the learners to explain them in intermediary language. As soon as the teacher feels that translation is not needed, namely, the unknown words or phrases do not interfere with understanding the text and using it; translation becomes the language learner's individual choice.

What language learner already knows, gives him a positive self-esteem, allowing him to look at the yet unknown without suspicion. Therefore, when involving translation, the language teacher should focus more attention on the new language elements and not ask students to translate what the learner already should know from previous studies. Though, if it is required, it can be seen as a motivating activity when translating language learner gets a confirmation that they know and understand a lot of the target language. As is known, understanding in reading or listening - perceptive skills - preceeds always productive skills. It is worth using the target language as a motivating factor when learning the target language (see also Mogahed, 2011).

Sometimes when you need to get a more accurate meaning, for example, šşūnis ('shed') or ligzda ('nest'), which learners do not also know in English being the intermediary language, either a third language - the native language - is involved in the translation process. As mentioned before, the availability of electronic dictionaries in mobile phones makes this process much easier and faster.

In this respect, the so-called transparent vocabulary - international words or phrases, whose pronunciation/spelling and meaning students are already known to students, such as kiwi, garage, mango yogurt. Those are words whose meaning and form are recognized and understood immediately because they are similar to corresponding native language words. Transparent vocabulary is "the first key to information decoding" (Gridina, 2006, p. 148). Latvian language as a foreign language is often learned in a plurilingual learning environment in which language learners use knowledge of several languages to learn the target language. Plurilingual approach "is based on the belief that learners of a new language look for similarities between the new language they are learning and others they already know and that in communicative situations the influence of those familiar languages appears in the use 
of the new language" (Bliska, 2015, p. 5). A person does not learn every language in isolation but forms links with the languages known to them, constructing metacognitive strategies, called language acquisition and is also used in language use. In the process, it does not matter which language "promotes recognition" (Bliska, 2015, p. 92).

One of the arguments why translation as part of foreign language learning is not considered appropriate is the fact that getting to know the meaning of the word by translating it.It is used in an instant action (the sentence is understood), but you do not memorize it, because you do not create associations which can be done, for example, by using pictures or detailed explanations. The quickest way to understand the unknown word is to translate it in the language the learner knows. However, it does not promote the memorization process. Therefore, if the translation is used in the language learning, learners must work with their dictionaries - their notes where all the new words are recorded and later remembered.

Using personal dictionaries ensures learning the meanings of the word, but does not guarantee its inclusion in active vocabulary; therefore the new words have to be included in the further learning process, both texts, and tasks, several times. If learners still do not understand the translated word, the teacher has to return to the first context in which the word was used. In this process, it is better to use the target language rather than translation, as in this way associations are created that promote memorizing the word. The use of cognitive effort and associative thinking to recall the meaning of a translated word is an important part of foreign language learning.

Both during and after the lesson when students do different tasks independently, translation is done with the help of a bilingual dictionary. When working with dictionaries,you need to focus on the lexical and grammatical aspect of the Latvian translation. At the early stage of language learning, students find it difficult to choose the best translation if the dictionary offers some options. Students have not formed the feeling for the foreign language yet. Thus they trust the dictionary and use the first word the dictionary offers.

Some foreign students are interested in the use of bilingual dictionaries in paper format; therefore they ask the teacher to suggest which one would be the most suitable for them. The authors have to admit that both English-Latvian and Latvian-English dictionaries lack metalinguistic information, which is important for Latvian language learners. Let us consider the verb to buy ('pirkt'). The English-Latvian dictionary gives the English pronunciation of the word, states what part of speech it is, provides the dominant forms of the verb and the translation into Latvian is given, as well as prefixes that change the meaning of the verb are added (Kalnina, 2001, p. 37). In the Latvian-English dictionary, the information on the verb pirkt ('to buy') is scarce - only the English translation and pronunciation of the verb are given (Kalniña, 2002, p. 476).

\section{Conclusions}

To conclude it has to be admitted that when using translation, one must take into account the individual needs of learners, the process of their thinking when they want to understand the meaning of syntactic units not only at lexical but also at a grammatical level. Metalinguistic explanation in the intermediary language can be used both in simple cases to show the difference between phrases (for example, Es esmu meita ('I am a daughter')and Man ir meita ('I have a daughter') where the dative case is necessary instead of the nominative case compared to the rule of the English language and in more complex situations in which misunderstandings have arisen. $91.43 \%$ of the respondents enjoy translation tasks, only $8.57 \%$ of answers are negative. Word translation has got the highest evaluation - 4.23 for translation from a foreign language (meaning Latvian) into English (being the intermediary language) and 4.15 in a five-point scale for translating from English into Latvian. As elementary learners, students use bi-lingual dictionaries more often than explanatory ones.

Although in language acquisition pictures and images can ensure the perception of the meaning of the word, in the translation process dictionaries help most of all. Taking into account today's situation when the Latvian language as a flective language may also be a foreign language, the compilers of bilingual dictionaries should supplement Latvian language dictionaries with metalinguistic information to make them useful for learning the Latvian language as a foreign language. Diverse linguistic experience, the difference among language systems, students' language attitudes establishes the purposeful use of translation in foreign language acquisition. 


\section{References}

Bliska, Inga. (2015). Franču valoda kā trešā valoda Latvijā: leksiski semantiskais mācību līmenis. [French as a third language in Latvia: lexical semantic study level]. Zin. vad. Diāna Laiveniece. [Promocijas darbs filologijāa.] Liepājas Universitāte.

Carreres, Angeles. (2006, December). Strange bedfellows: Translation and Language teaching. The teaching of translation into L2 in modern languages degrees; uses and limitations. $6^{\text {th }}$ Symposium on Translation, Terminology and Interpretation in Cuba and Canada. Retrieved February 5, 2017, from http://www.cttic.org/ACTI/2006/papers/Carreres.pdf

Cook, Guy. (2010). Translation and Language Teaching. Oxford: Oxford University Press.

Council of Europe. (2001). Common European Framework of Reference for Languages: Learning, Teaching, Assessment. Cambridge University Press. Retrieved March 27, 2017, from https://www.coe.int/t/dg4/linguistic/Source/Framework_EN.pdf Dagiliene, Inga. (2012). Translation as a Learning Method in English Language Teaching. Kalbu studijos, Nr. 21. Retrieved March 6, 2017, from http://www.kalbos.ktu.lt/index.php/KStud/article/ viewFile/1469/2164

English Language Teaching Global Blog. (2011). Translation in language teaching and learning: Guy Cook on Translation. Oxford University Press. Retrieved February 5, 2017, from https://oupeltglobalblog.com/2011/10/20/translation-inlanguage-teaching-and-learning/

Fernández-Guerra, Ana. (2014). The Usefulness of Translation in Foreign Language Learning: Students' Attitudes. International Journal of English Language \& Translation Studies, Vol. 2 (1), pp. 153-170.

Fisher, Robert. (1990). Teaching Children to Think. Oxford: Basil Blackwell.

Gridina, Jel̦ena. (2006). Itālu valoda Rīgas ielās. [The Italian language in the streets of Rīga]. Letonikas pirmais kongress. Valodniecības raksti. Rīga: Latvijas Zinātņu akadēmija, 146.-152. lpp.

Kalniņa, Dzintra. (2001). Latviešu-angļu/anglulu-latviešu vārdnīca. [Latvian-English/English-Latvian dictionary]. Rīga: Avots. Leonardi, Vanessa. (2011). Pedagogical Translation as a Naturally-Occurring Cognitive and Linguistic Activity in Foreign Language Learning. Annali Online di Lettere - Ferrara, Vol. 1-2, pp. 17-28 Retrieved March 6, 2017, from http://annali.unife.it/lettere/article/viewFile/234/183

Malmkjær, Kirsten. (1998) Introduction: Translation and Language Teaching. Translation and Language Teaching: Language Teaching and Translation. Kirsten Malmkjær (Ed.). Manchester: St. Jerome, pp. 1-11.

Marqués-Aguado, Teresa, Solís-Becerra, Juan. (2013). An Overview of Translation in Language Teaching Methods: Implications for EFL in Secondary Education in the Region of Murcia. Revista de Lingüistica y Lenguas Aplicadas, Nr. 8. Retrieved March 6, 2017, from http://polipapers.upv.es/index. php/rdlyla/article/viewFile/1161/1669

Mogahed, Mogahed M. (2011). To Use or not to Use Translation in Language Teaching. Translation Journal, Vol. 15 (4). Retrieved February 5, 2017, from http://translationjournal.net/journal/58education.htm

Mutore, Anna. (2013). Tulkošanas aktualizēšana svešvalodas apguvē: frankofono valodnieku skatījums. [Re-introducing of translation in foreign language learning: Francophone linguistic perspective.].Valodu apguve: problēmas un perspektīva, IX : zinātnisko rakstu krājums. Liepāja: LiePA, 94.-100. lpp.

Šalme, Arvils, Auziņa, Ilze. (2016).Latviešu valodas prasmes līmeņi: pamatlìmenis A1, A2, vidējais līmenis B1, B2. [Latvian Language Reference Levels: Elementary A1, A2, Intermediate B1, B2].Rīga: Latviešu valodas ağentūra.

Skujiņa, Valentīna. (2011). Lingvodidaktikas terminu skaidrojošā vārdnīca. [Dictionary of the language learning methodology terms]. Skujiņa Valentīna (Ed.). Rīga: Latviešu valodas aǵentūra.

Tsagari, Dina, Floros, Georgios. (2013). Translation in Language Teaching and Assessment. Dina Tsagari, Georgios Floros (Eds.). Newcastle upon Tyne: Cambridge Scholars Publishing. 